\title{
PHYSICAL CHARACTERISTICS OF JACKFRUIT AT DIFFERENT HARVESTING TIMES
}

\author{
I. J. Irin ${ }^{1}$, M. A. Haque ${ }^{2}$, M. G. Rabbani ${ }^{2}$ and P. K. Biswas ${ }^{3}$ \\ ${ }^{1}$ Assistant Thana Education Officer, Motijheel, Dhaka. \\ ${ }^{2}$ Professor, Department of Horticulture,BAU, Mymensingh. \\ ${ }^{3}$ Professor, Department of Agronomy, SAU, Dhaka \\ Corresponding author: isratateo@gmail.com
}

Key words: Physical characteristics, harvesting time, jackfruit

\begin{abstract}
An experiment was conducted at the Jackfruit Research Project, Horticulture farm of Bangladesh Agricultural University, Mymensingh during the period from December 2002 to July 2003 with the objectives to determine the physical characteristics of three types of jackfruit at different harvesting time vis a vis appropriate time of harvest of them. Physical craracteristics of three types indicated that bulb weight (\%) decreased and rind weight (\%) increased at later stages of harvesting. The bulb of Ghila was very soft at early harvesting stage but firm at late harvesting. The edible portion was found to be the highest (59.95\%) in mid harvesting time and Dorosha type gave the maximum (55.21\%). The fruits of late harvesting time had viviparous seed. Early and mid harvesting times were found to be better in all three types of Jackfruit and Ghila was found to be superior.
\end{abstract}

\section{Introduction}

Jackfruit (Artocarpous heterophyllous Lam.) is the national fruit of Bangladesh. The production of jackfruit in Bangladesh was 2,67,495 tons from an area of 66,765 hectares (BBS, 2003). Jackfruit may contribute to the nutrition of the people as a source of minerals, vitamins, calcium, iron, $\beta$-Carotene, thiamine and sugar etc. Unripe jackfruit has a remarkably similar texture to chicken, making jackfruit an excellent vegetarian substitute for meat. In fact, jackfruit is sometimes referred to as "vegetable meat". Kamaluddin (1966) reported that, being cross pollinated and mostly seed propagated the jackfruit has innumerable types considering the fruit characteristics differing in density of spikes on the rind, bearing habit, size, shape, quility of fruit and period of maturity. Haque (1993) identified three types of jackfruit such as Khaja, Ghila and Dorosha. Anonymous (1997) identified that the texture of bulb become crispy when the fruits harvested in later part of season. Anonymous (1997) worked with physico chemical characteristics of Ghila type at three different harvesting times and reported that physical characteristics such as weight of fruit, bulb, seed rachis, rind and their percentage were varied at different harvesting time. Viviparity were found highest in late harvesting (Azad, 1989). Early harvesting time had no viviparous seed. Haque (1993) reported that the percentage of rind increased with delay of harvesting, while bulb percentage showed the reverse trend. Anonymous (1995) found Ghila contain highest number of bulb per fruit and rind percent was highest in Khaja. Therefore the present trial was undertaken to find out the appropriate time of harvesting for three types and physical characteristics of jackfruit at different harvesting. 


\section{Materials and Methods}

The experiment was carried out from 2002 to July 2003. Three types of jackfruit were selected from Jackfruit Research Project at the Horticulture Farm of Bangladesh Agricultural University, Mymensingh. The selected plants were three types namely Khaja, Ghila and Dorosha and harvested at different times namely early harvesting, mid harvesting and late harvesting. The selected plants have been grown on medium high land of old Brahmaputra flood plain soil tract of Bangladesh. The soil was sandy loamy having $\mathrm{pH}$ 6.6. The study was conducted in a randomized complete block design with three replications. Time and types served as different factors. Thus there were three times of harvesting and three types of jackfruit. Mature jackfruits were collected from the plant and kept at ambient temperature for further study. Analysis was done in the laboratory of the Department of Food Technology and Rural Industry, Bangladesh Agricultural University, Mynensingh. By using different parameters physical characteristics were studied. The collected data were analyzed statistically and adjusted with least significant difference test (LSD) at $5 \%$ and $1 \%$ level of probability.

\section{Result and Discussion}

The result on the study of size (length $\mathrm{x}$ width $\mathrm{x}$ circumpherence), shape and weight of the three types jackfruit at different harvesting times are shown in Tables 1 and 2 . Among the different harvesting times, mid harvesting fruit gave maximum average fruit length $(55.67 \mathrm{~cm} \mathrm{x}$ wide $31.45 \mathrm{~cm} \times$ circumference $83.11 \mathrm{~cm}$ ) while it was minimum at early harvesting and Khaja type gave maximum fruit weight $(14.02 \mathrm{~kg})$ at mid harvesting while minimum $(12.31 \mathrm{~kg})$ at early harvesting in Dorosha. The highest size was $53.44 \mathrm{~cm}, 29.78 \mathrm{~cm}$ and $81.22 \mathrm{~cm}$ obtained from Ghila followed by Dorosha and Khaja. The present result were close to the findings of Bhatia et al. (1955) and Mowry (1953) who reported that the fruits to be 20.32 to $91.44 \mathrm{~cm}$ long and 15.24 to $50.80 \mathrm{~cm}$ wide. Hossain and Haque (1977) stated that the mean length and diameter of fruits were 31.6 and $22.4 \mathrm{~cm}$. The interaction effect had significant response. Mowry (1953) mentioned that average weight of fruit ranges from $4.50 \mathrm{~kg}$ to $18.00 \mathrm{~kg}$.

The response for lesser weight of fruits at the late season might be due to lack of adequate supply of nutrients since plants might be exhausted of their food because of development of early season fruits. Anonymous (1997) who reported that fruits of mid harvesting time were larger while those in late season were smaller.

The highest number (186.11) of bulbs was obtained from early harvesting time in Ghila (182), while it was minimum (142.24) at late harvesting in Khaja (150) (Table 1 and 2). The present result has similarity with Hossain and Haque (1977). They found that the number of bulb varied from 30 to 185 . The size of bulb was found the highest $(7.71 \mathrm{~cm} \times 4.89 \mathrm{~cm})$ at mid harvesting time while it was minimum $(5.27 \mathrm{~cm} \times 3.30 \mathrm{~cm})$ at early harvesting (Table 1). The greater bulb length and diameter was found in Khaja $(6.96 \mathrm{~cm} \times 4.34 \mathrm{~cm})$ compared to Ghila $(5.67 \mathrm{~cm} \times$ $3.86 \mathrm{~cm})$. Bhatia et al. (1955) reported that the bulb size is $(2.54$ to $6.35 \mathrm{~cm} \times 0.64$ to $3.81 \mathrm{~cm}$. Hossain and Haque (1977) reported that the size of bulb was $(4.1$ to $8.5 \mathrm{~cm} \times 2.62$ to $5.0 \mathrm{~cm})$. 
a

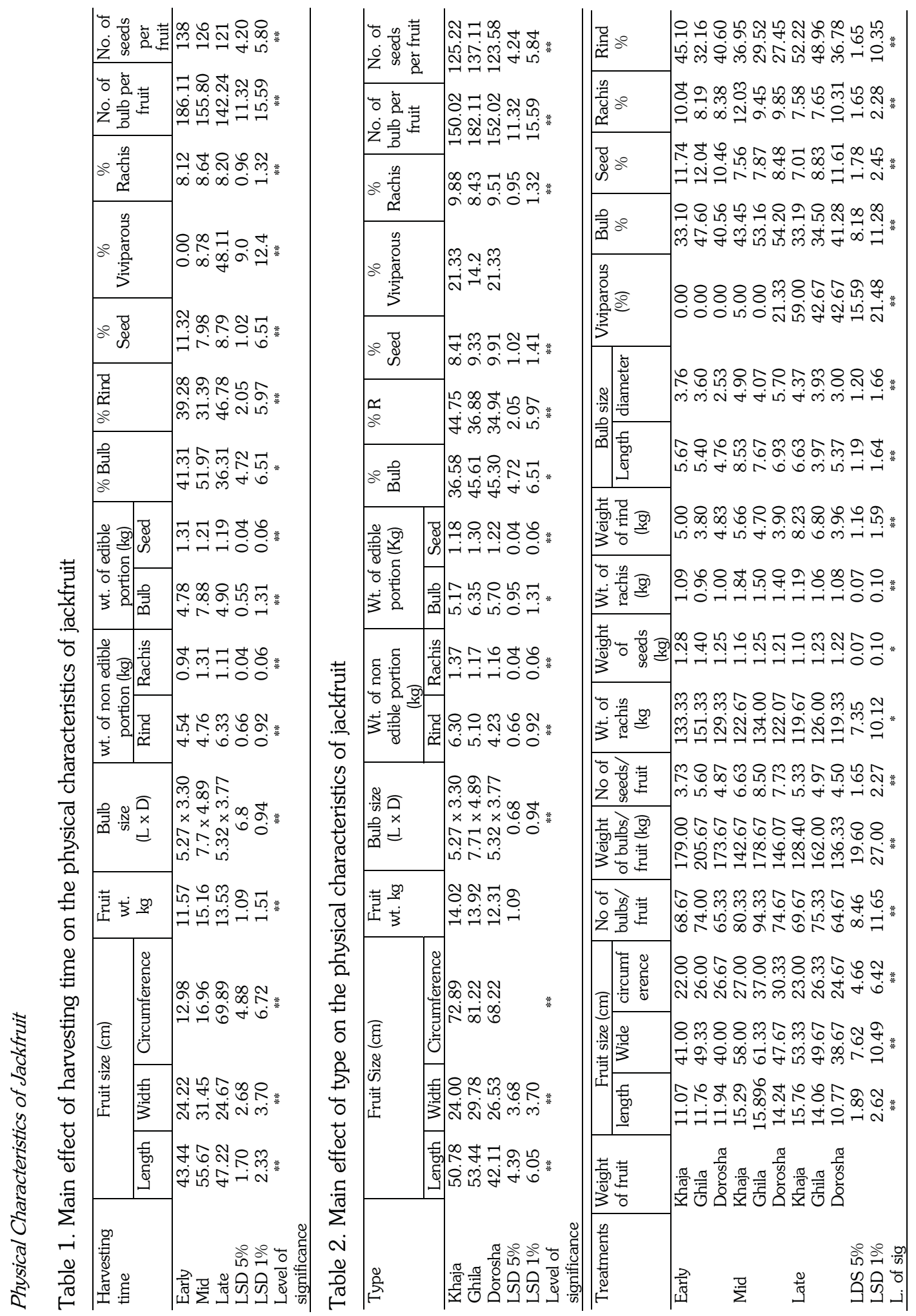


The significant interaction between harvesting time and type of jackfruit indicated that mid harvesting time in association with Khaja type exerted maximum effect in producing higher bulb length $(7.67 \mathrm{~cm})$ and minimum $(3.97 \mathrm{~cm})$ with the combination of Dorosha with early harvesting time (Table 3). The result of bulb weight allowed that mid harvesting had comparatively greater bulb weight $(7.62 \mathrm{~kg})$ with Ghila than that of late one $(4.90 \mathrm{~kg})$ (Table 1$)$. The bulb weight of jackfruit also varied among three types. Ghila type had maximum bulb weight $(6.35 \mathrm{~kg})$ while minimum in Khaja $(5.17 \mathrm{~kg})$. Seed weight of jackfruit at different harvesting times are shown in Tables 1 . The maximum seed weight $(1.3 \mathrm{~kg})$ was obtained from Ghila and minimum $(1.1 \mathrm{~kg})$ from Khaja. Again early harvesting fruit gave maximum $(1.31 \mathrm{~kg})$ average seed weight followed by late harvesting $(1.19 \mathrm{~kg})$ and mid harvesting fruit $(1.21 \mathrm{~kg})$. The interaction effects of harvesting time and type in respect of seed weight found to be significant (Table 3). The results on the number of seeds per fruit showed that the Ghila produced maximum number of seeds (137.11) followed by Khaja (125.22) and Dorosha (123.58). The average of 138.00, 126.24 and 121.67 seeds per fruit was found in early, mid and late harvesting times respectively. Interaction between harvesting times and type was found to be significant (Table 3).

Khaja type produced maximum average rachis weight $(1.37 \mathrm{~kg})$ while it was minimum in Dorosha $(1.16 \mathrm{~kg})$. On the other hand, mid harvesting time had maximum weight of rachis $(0.58 \mathrm{~kg})$ which was significantly different from late $(1.05 \mathrm{~kg})$ and early $(0.94 \mathrm{~kg})$ harvesting. The present results were supported by the findings of Anonymous (1997) who reported that Khaja produced maximum average rachis weight while it was minimum in Dorosha. Late harvesting time produced maximum average rind weight $(6.33 \mathrm{~kg})$ which was significantly different from earlier one (Table 1). The weight of rind also varied significantly among three types. Khaja had the maximum average rind weight $(6.30 \mathrm{~kg})$ while the minimum was found in Dorosha $(4.23 \mathrm{~kg})$. The present result were very close to the findings of Anonymous (1995) who reported that khaja contained maximum weight of rind and minimum obtained from Ghila. Anonymous (1997) mentioned that mid harvesting produced $3.02 \mathrm{~kg}$ of rind while it was $2.37 \mathrm{~kg}$ at the early harvesting time. The interaction effect between harvesting time and type also found to be significant. Harvesting time had significant influence on the percentage of viviparous seed. The maximum number of viviparous seed $(48.11 \%)$ was found by late harvesting time while early harvesting time had no viviparous seed (Table 3). Khaja and Dorosha produced maximum average viviparous seeds (21.33\%) while it was minimum in Ghila (Table 4). The results supported by the findings of Habib (1973) and Azad (1989). Anonymous (1997) reported the maximum percentage of viviparous seed was obtained by late harvesting. Islam (1993) observed that khaja contain 30.5\% viviparous seed where as Ghila contain only 11\%. The interaction effect between harvesting time and types also found significant response.

The bulb percentage was found the highest $(50.27 \%)$ at mid harvesting time followed by late (36.32\%) (Table 1) but seed percentage was found highest (11.41\%) at early harvesting time (Table 1) and dorosha produced maximum (9.91\%) (Table 2). Significant variation also present in three types of jackfruit. The type Ghila $(45.61 \%)$ produced maximum average percentage of bulb followed by Dorosha $(45.30 \%)$ and Khaja $(36.58 \%)$. The results were very close to the findings of Bhatia et al. (1955) and Purseglove (1968). They obtained 15.2 to 49.8 percent bulb in the fruit. The interaction effect of harvesting time and type was found to be significant (Table 3). The result of seed study agreed with the findings of Bhatia et al. (1955) that seed weight amounting to 11.5 percent of total weight of fruit which is quite similar to the type Ghila and Dorosha. Islam (1993) stated that Khaja type contained 5.65 percent of seed and Ghila type contained 4.07 percent. The interaction were found to be significant. The maximum percentage of rachis was found at mid harvesting time which was followed by early and late harvesting time. On the other hand maximum percentage (9.88\%) of rachis was found from Khaja type and minimum (8.43\%) 
Physical Characteristics of Jackfruit

from Ghila variety which was agreed with the findings of Hossain (1976) who objerved ten different type jackfruit and found average rachis to be $9.16 \%$. The interaction in respect of percent of rachis was significant (Table 3). It was observed that the rind percentage was found maximum (45.99\%) at late harvesting time while it was minimum at mid harvesting time (31.30\%). The percentage of rind also varied among three type of jackfruit. Khaja pruduced the highest percentage $(44.75 \%)$ of rind which was followed by Ghila (36.88\%) and Dorosha (34.94\%). The present results were very close to the findings of Anonymous (1997) and Bhatia et al. (1955). Hossain (1976) observed that rind contents of the jackfruit of ten types were in the range from $16.48 \%$ to $76.89 \%$. The interaction between harvesting time and type were found to be significant.

\section{Conclusion}

Based on the results it might be concluded that mid and early harvesting times were better for the jackfruit but late harvesting time was not desirable as the quality of fruits deteriorates with time.

\section{References}

Anonymous. 1995. A study on the physico-chemical characteristics of three type of jackfruit at different stages of ripening and during storage at different condition. M.Sc.(Ag) thesis, Dept. of Horticulture. Bangladesh Agricultural University, Mymensingh.76p.

Anonymous.1997. Study on the physico-chemical characteristics of jackfruit at different harvesting time. M.Sc.(Ag.) thesis, Dept. of Horticulture. Bangladesh Agricultural University, Mymensingh. 50p.

Azad, A. K. 1989 Studies on floral biology, pattern of fruitset and quality of fruitis borne in different section, of jackfruit plants. M.Sc. (Ag.) thesis, Dept. of Horticulture, BAU, Mymensingh. pp.12-14.

BBS. 2003. Year book of Agricultural Statistics of Bangladesh, Bangladesh Bureau of Statistics, Statistics Division, Ministry of Planning.Government of the Peoples Republic of Bangladesh. pp.88-89.

Bhatia, B. S., C. S. Siddappa and G. Lal. 1955. Composition and nutritive value of jackfruit. Ind. J. Agric. Sci. 25(4): 30-36.

Habib, A. F. 1973. Vivipary in Artocarpus heterophyllus Lam, Mysore. J. Agric. Sci. 7(1): 120-121.

Haque, M. A. 1993. Collection and evaluation of different jackfruit clones of Bangladesh, BAU Res. Prog. 7: 209-215.

Hossain, M. and A. Haque. 1977. Studies on physical characteristies of jackfruit. Bangladesh Hort. 5(1): $9-14$

Hossain, M. 1976. Studies on the physical characteristics and nutritive value of jackfruit (Artocarpous heterophyllus Lam). M. Sc. (Ag). thesis, Department of Horticulture, BAU, Mymensingh.55p.

Islam, M. O. 1993. Studies on seed germination and seedling Morphologies of jackfruit (Artocarpous heterophyllous) in relation to growth. M. Sc. thesis. Dept. of Crop Botany. BAU, Mymensingh. pp.22-30.

Kamaluddin, A. S. M. 1966. Phaler Chash (in Bangla). Kamnun Nahar, 41 F, Ajimpur Housing Estage, Dhaka. pp.198-221. 
Irin et al.

Mowry, H. 1953. Miscellaneous Tropical and Sub-tropical Florida Fruits. Bulletin, 156, Univ. of Fla. Ag. Ext. Serv., Gainesville. pp.29-31.

Purseglove, J. W. 1968. Tropical Crops. Dicotyledons 2. Longmans, Green and Co. Ltd., London and Marlow. pp.384-336. 